\title{
DETERMINAN SOSIAL KESEHATAN KEJADIAN STUNTING PADA BALITA 24-59 BULAN DI KABUPATEN KUNINGAN
}

\author{
Fitri Kurnia Rahim, Russiska
}

Sekolah Tinggi Ilmu Kesehatan Kuningan Garawangi

fikura.zone@gmail.com

\begin{abstract}
Abstrak
Diseluruh dunia, sekitar 162 juta balita mengalami kejadian stunting Prevalensi stunting di Indonesia lebih tinggi daripada negara-negara lain di Asia Tenggara. Tujuan penelitian ini adalah untuk mengetahui mengetahui bagaimana hubungan determinan sosial kesehatan dengan kejadian stunting.

Penelitian dilakukan di Kabupaten Kuningan. Jenis penelitian menggunakan desain kasus kontrol. Populasi penelitian adalah balita yang berumur 24-59 bulan di wilayah Kabupaten Kuningan. Adapun besar sampel dalam penelitian yaitu sebanyak 94 orang dengan ratio 1:1. Sehingga jumlah sampel sebanyak 188 orang. Instrumen penelitian berupa kuesioner dan alat ukur tinggi badan microtoise. Analisis data dilakukan melalui analisis univariat, bivariat (uji chi-squre) dan logistik berganda sederhana.

Hasil penelitian menunjukan sebagian besar anak stunting memiliki ibu dengan latar belakang pendidikanya $\leq$ SMP. Anak balita yang memiliki ibu dengan latar belakang pendidikan $\leq$ SMP 2,74 kali berisiko mengalami kejadian stunting dibandingkan anak yang memiliki ibu dengan latar belakang pendidikan > SMP. Latar belakang pendidikan ibu merupakan faktor yang berhubungan signifikan dengan kejadian stunting. Latar belakang pendidikan ibu merupakan prediktor yang signifikan dengan kejadian stunting. Perlu adanya peningkatan upaya promosi kesehatan tentang gizi anak serta kesehatan kehamilan pada ibu balita. Pembentukan komunitas literasi kesehatan pada masyarakat perempuan perlu ditingkatkan.
\end{abstract}

Keyword : stunting, balita 24-59 bulan, pendidikan ibu, karakteristik

\section{Pendahuluan}

Stunting (balita pendek) merupakan permasalahan penting yang harus diperhatikan. Stunting berdampak pada kognitif dan perkembangan anak pada masa yang akan datang. Diseluruh dunia, sekitar 162 juta balita mengalami kejadian stunting (Kementerian Kesehatan, 2016). Prevalensi stunting di Indonesia lebih tinggi daripada negara-negara lain di Asia Tenggara. Prevalensi stunting nasional mencapai 37,2 $\%$, meningkat dari tahun $2010(35,6 \%)$ dan 2007 (36,8\%). Hasil pemantauan status gizi menunjukan terdapat kenaikan prevalensi stunting dari tahun 2016 sampai 2017 yaitu dari 27,5\% menjadi 29,6\% (Kementrian Kesehatan, 2018). Menurut World Health Organization batas maksimal stunting bayi adalah $20 \%$. Angka stunting di Jawa Barat mencapai 29,2\% (2017) atau mengalami kenaikan dari 25,1 \% (2016). Prevalensi stunting di Kab. Kuningan mencapai $42 \%$ pada tahun 2013 (TNP2K, 2017).

Stunting diseababkan oleh banyak faktor seperti status gizi ibu hamil/balita, pengetahuan ibu, antenatal atau postnatal care, makanan bergizi, air bersih dan sanitasi (Kementerian Kesehatan, 2015), berat badan lahir rendah, tinggi dan berat 
JURNAL ILMU KESEHATAN BHAKTI HUSADA:

HeALTH SCIENCES JOURNAL, Vol. 10 No. 02, DeSEMBER 2019 DOI: $10.34305 / J I K B H . V 10 I 2.103$

badan orang tua, status pendidikan orang tua (Bove, Miranda, Campoy, Uauy, \& Napol, 2012; Deshmukh, Sinha, \& Dongre, 2013; Lee, Houser, Must, de Fulladolsa, \& Bermudez, 2010; Cut Novianti Rachmi, Kingsley Emwinyore Agho, Mu Li, \& Louise Alison Baur, 2016; Cut Novianti Rachmi, Kingsley E Agho, Mu Li, \& Louise Alison Baur, 2016), status ekonomi (Bove et al., 2012; Semba et al., 2007), status pekerjaan, dan kejadian anemia (Deshmukh et al., 2013). Berdasarkan beberapa hasil penelitian sebelumnya, determinan sosial kesehatan erat kaitanya dengan kejadian stunting. Faktor tinggi badan orang tua, latar belakang pendidikan dan pendapatan keluarga menjadi hal yang perlu dianalisis. Latar belakang pendidikan ibu memiliki kaitan yang erat dengan status kesehatan anak khususnya yaitu status gizi anak (Abuya, Ciera, \& Kimani-Murage, 2012). Anak yang dilahirkan dari ibu yang berpendidikan akan sedikit mengalami kejadian kurang gizi (Abuya et al., 2012). Hal ini, dapat disebabkan karena ibu yang berpendidikan lebih banyak mendapatkan atau mengetahui informasi kesehatan karena banyak terpapar. Pendidikan ibu juga terkait bagaimana cara atau pola mengasuh anak kaena hal ini dapat berpengaruh terhadap status gizi anak. Tujuan penelitian ini adalah untuk mengetahui lebih dalam faktor determinan sosial kesehatan yang berhubungan dengan kejadian stunting. Penelitian ini bertujuan untuk menganalisis apakah determinan sosial kesehatan berhubungan dengan kejadian stunting di wilayah Kabupaten kuningan.

\section{Metode Penelitian}

Penelitian ini menggunakan desain observasional dengan rancangan penelitian case control (kasus kontrol). Populasi dalam penelitian ini adalah seluruh balita usia 24-59 bulan di wilayah Kab.
Kuningan. Subyek dalam penelitian adalah semua kasus dan kontrol yang dipilih dengan perbandingan kasus dan kontrol 1:1. Kasus adalah balita stunting usia 24-59 bulan dengan indeks Z-score TB/U <-2 SD dan kontrol adalah balita usia 24-59 bulan dengan indeks z-score TB/U -2 SD sampai + 2SD. Responden dalam penelitian ini adalah ibu balita yang terpilih menjadi subjek penelitian. Besar sampel minimal yang diperlukan dihitung berdasarkan rumus Lemeshow (1991) didapatkan sampel minimal sebanyak 94 orang dengan perbandingan kasus dan kontrol 1:1, totalnya adalah 188 orang. Kriteria inklusi dalam penelitian ini adalah balita usia 24-59 bulan yang tinggal menetap di wilayah Kab. Kuningan. Teknik pengambilan sampel menggunakan simple random sampling.

Penelitian dilaksanakan di Kabupaten Kuningan Jawa Barat pada bulan Mei-Juli 2019 Variabel terikat penelitian ini adalah tinggi badan orang tua, yaitu ukuran tubuh linier ayah dan ibu yang diukur menggunakan microtoise dengan ketelitian $0,1 \mathrm{~cm}$ dari ujung kaki sampai kepala dengan kategori ibu pendek bila tinggi badan $<150 \mathrm{~cm}$ dan normal bila $\geq 150$ $\mathrm{cm}$, sedangkan ayah pendek bila tinggi badan $<162 \mathrm{~cm}$ dan normal bila $\geq 162 \mathrm{~cm}$. Pendapatan perkapita yaitu jumlah pendapatan keluarga selama sebulan yang dinyatakan dalam rupiah perbulan. Pendidikan orangtua adalah jenjang pendidikan formal terakhir yang ditamatkan ibu dan ayah berdasarkan kepemilikan ijazah. Instrumen yang digunakan adalah kusioner dan alat ukur tinggi badan dewasa. Analisis data menggunakan program statistik. Analisis univariat untuk mengetahui distribusi frekuensi dari variabel yang diteliti. Analisis bivariat menggunakan uji Chi square dengan $\alpha 0,05$. Jika pada tabel memiliki expected value kurang dari 5 lebih dari 20\% digunakan uji Fisher Exact. Analisis multivariat menggunakan uji Regresi Logistik Ganda. 


\section{Hasil}

Tabel 1. Distribusi Frekuensi Karakteristik Keluarga dan Hubungannya Dengan kejadian Kejadian Stunting di Kabupaten Kuningan Tahun 2019

\begin{tabular}{|c|c|c|c|c|}
\hline Variabel & $\begin{array}{c}\text { Stunting } \\
n(\%)\end{array}$ & $\begin{array}{c}\text { Non-Stunting } \\
\text { n }(\%)\end{array}$ & OR $(95 \% \mathrm{CI})$ & P-Value \\
\hline \multicolumn{5}{|c|}{ Tinggi Badan Ibu (cm) } \\
\hline$<150$ & $49(52.1)$ & $38(40.4)$ & 1.60 & 0.108 \\
\hline$\geq 150$ & $45(47.9)$ & $56(59.6)$ & $(0.90-2.86)$ & \\
\hline \multicolumn{5}{|c|}{ Tinggi Badan Ayah $(\mathrm{cm})$} \\
\hline$<163$ & $45(47,9)$ & $32(34,0)$ & 1,78 & 0,054 \\
\hline$\geq 162$ & $49(52,1)$ & $62(66,0)$ & $(1,00-3,20)$ & \\
\hline \multicolumn{5}{|c|}{ Pendidikan Terakhir Ibu } \\
\hline$\leq \mathrm{SMP}$ & $83(88.3)$ & $69(73.4)$ & 2.73 & 0.009 \\
\hline$\geq$ SMA & $11(11.7)$ & $25(26.6)$ & $(1.26-5.95)$ & \\
\hline \multicolumn{5}{|c|}{ Pendidikan Terakhir Ayah } \\
\hline$\leq \mathrm{SMP}$ & $79(84.0)$ & $72(76.6)$ & 1.609 & 0.199 \\
\hline$\geq$ SMA & $15(16.0)$ & $22(23.4)$ & $(0.78-3.339)$ & \\
\hline \multicolumn{5}{|c|}{ Pendapatan Kepala Keluarga } \\
\hline$<1.500 .000$ & $61(64.9)$ & $48(51.1)$ & 1.77 & 0.055 \\
\hline$\geq 1.500 .000$ & $33(35.1)$ & $46(48.9)$ & $(0.99-3.18)$ & \\
\hline
\end{tabular}

Berdasarkan tabel 1 menunjukan pada kelompok balita stunting hampir setengahnya memiliki ibu yang tinggi badanya $<150 \mathrm{~cm}$ dan tinggi badan ayah $<163 \mathrm{~cm}, 52,1 \%$ dan 47,9 $\%$. Sebagian besar kelompok balita stunting memiliki ibu dan ayah berlatar belakang pendidikan terakhir $\leq$ SMP, $83 \%$ dan $79 \%$. Selain itu, lebih dari setengahnya balita stunting memiliki pendapatan kepala keluarga < 1.500 .000 (64,9\%). Pada kelompok balita tidak stunting sebagian besar memiliki ibu dan ayah yang tinggi badanya baik, sebagian besar memiliki ayah dan ibu berlatar belakang pendidikan terakhirnya $\leq$ SMP, 73,4 \% dan 76,6 $\%$, serta sekitar setengahnya memiliki pendapatan keluarga $\geq 1.500 .000$ yaitu $48,9 \%$.

Pada tabel 1 menunjukan bahwa variabel yang berhubungan signifikan $(p<0,05)$ dengan kejadian stunting yaitu tinggi badan ayah, pendidikan terakhir ibu dan pendapatan keluarga. Adapun faktor yang tidak berhubungan dengan kejadian stunting yaitu variabel tinggi badan ibu dan latar pendidikan ayah..

Tabel 2.Prediktor Kejadian Stunting di Kab. Kuningan, 2019

\begin{tabular}{|c|c|c|c|c|c|}
\hline \multirow[t]{2}{*}{ Variabel } & \multirow[t]{2}{*}{$B$} & \multirow[t]{2}{*}{ Adj OR } & \multicolumn{2}{|c|}{$95 \% \mathrm{CI}$} & \multirow[t]{2}{*}{ P-value } \\
\hline & & & Lower & Upper & \\
\hline Tinggi Badan Ibu (cm) & & & & & \\
\hline $\begin{array}{l}<150 \\
\geq 150\end{array}$ & 0,400 & $\begin{array}{c}1,429 \\
1\end{array}$ & 0,821 & 2,710 & 0,189 \\
\hline $\begin{array}{l}\text { Tinggi Badan Ayah } \\
\text { (cm) }\end{array}$ & & & & & \\
\hline $\begin{array}{c}<163 \\
\geq 162 \\
\text { Pendidikan Terakhir }\end{array}$ & 0,490 & 1,633 & 0,885 & 3,013 & 0,117 \\
\hline
\end{tabular}




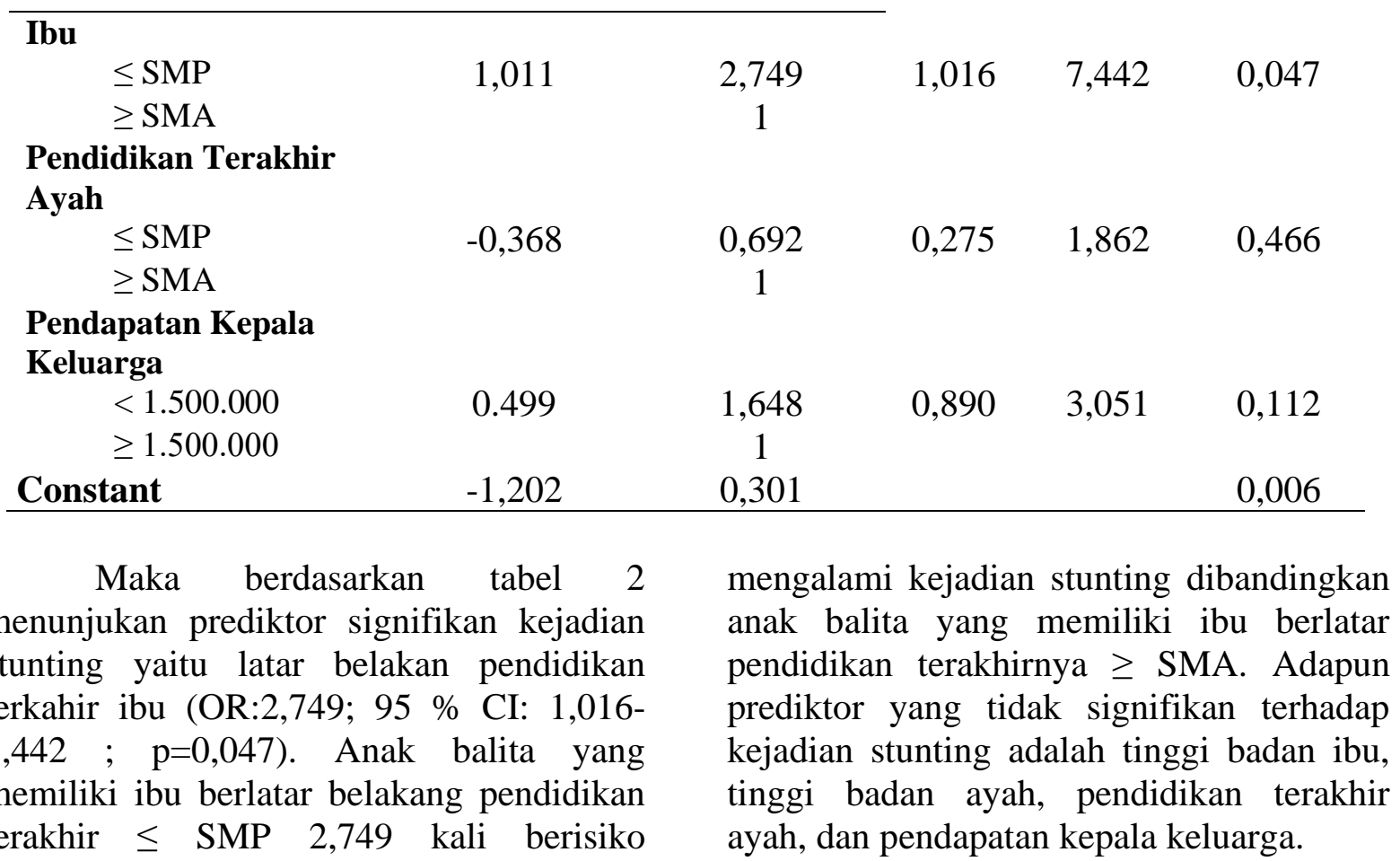

\section{Pembahasan}

Pendidikan ibu memiliki hubungan yang signifikan dengan kejadian stunting pada anak 24-59 bulan. Pendidikan ibu merupakan prediktor signifikan terhadap kejadian stunting. Balita yang memiliki ibu berlatar pendidikan menengah kebawah 2,74 kali berisiko mengalami kejadian stunting dibandingkan balita yang memiliki ibu berlatar belakang pendidikan menengah atas atau lebih. Pendidikan sejalan dengan pengetahuan seseorang. Ibu yang memiliki latar belakang pendidikan menengah kebawah secara informal sistematikal pemikiranya masih kurang dan minimnya informasi yang didapatkan berdampak pada pola asuh yang diberikan pada anak. Hasil penelitian ini sejalan dengan penelitian sebelumnya terdapat hubungan signifikan antara latar belakang pendidikan ibu dengan kejadian stunting di Jambi begitu juga di Afrika (Abuya et al., 2012). Balita yang memiliki ibu berlatar belakang pendidikan menengah kebawah 1.6 kali berisiko mengalami stunting dibandingkan ibu berlatar belakang pendidikan menengah atas atau lebih (Laksminingsih, 2018). Ibu dengan tingkat pendidikan tinggi diharapkan memiliki sikap positif terhadap gizi makanan sehingga dapat membantu pemenuhan kebutuhan gizi yang cukup untuk keluarga. Selain itu, tingkat pendidikan juga memengaruhi kemampuan dalam menerima informasi mengenai gizi dan kesehatan anak. Selain itu, pendidikan ibu juga berkaitan dengan kemampuan ibu dalam memahami masalah kesehatan dan cara menangani masalah tersebut pada anaknya serta ibu yang berpendidikan tinggi mampu memahami lebih dalam instruksi medis untuk penyembuhan dan perawatan anak. Ibu yang berpendidikan kesehatan yang modern (Abuya et al., 2012). Dengan demikian latar belakang pendidian berkontribusi terhadap status gizi anak.

Penelitian ini mendapatkan bahwa variabel tinggi badan ibu tidak berhubungan dengan kejadian stunting. Hal ini dikarenakan masih ada faktor lain yang dapat berhubungan dengan stunting. tinggi juga lebih terbuka dengan informasi 
JURNAL ILMU KESEHATAN BHAKTI HUSADA:

HeALTH SCIENCES JOURNAL, Vol. 10 No. 02, DeSEMBER 2019

DOI: $10.34305 / J I K B H . V 10 I 2.103$

Penemuan ini tidak sejalan dengan penelitian sebelumnya yang menyatakan bahwa tinggi badan orang tua itu berhubungan dan prediktor kejadian stunting (Lestari, Margawati, \& Rahfiludin, 2014). Adapun tinggi badan ayah berhubungan dengan kejadian stunting.

Latar belakang pendidikan ayah pada penelitian ini tidak berhubungan signifikan dengan kejadian stunting. Hal ini dikarenakan ada faktor lain yang berhbungan dengan kejadian stunting. Hal ini sejalan dengan penelitian sebelumnya yang menyatakan tidak ada hubungan signifikan antara pendidikan ayah dengan kejadian stunting (Lestari et al., 2014). Dalam penelitian ini menunjukan bahwa antara kelompok balita stunting dan non stunting mayoritas latar belakang pendidikanya $\leq$ SMP. Hal ini masih menjadi budaya dan persepsi masyarakat disebagian wilayah penelitian, bahwa setelah lulus sekolah SD atau SMP mereka diarahkan untuk bekerja atau berwirausaha oleh kedua orangtuanya. Mereka pergi merantau ke kota untuk bekerja ikut serta dengan masyarakat yang sudah bekerja di kota sebelumnya. Ayah yang memiliki latar belakang pendidikan menengah kebawah kurang memperhatikan informasi kesehatan balita dan ibu selama kehamilan.

Selain itu, pendapatan keluarga memiliki hubungan yang signifikan dengan kejadian stunting. Anak dengan pendapatan keluarga yang rendah memiliki risiko menjadi stunting sebesar 1,77 kali dibandingkan pada anak dengan pendapatan keluarganya tinggi. Penelitian ini sejalan dengan hasil penelitian sebelumnya bahwa anak dengan pendapatan keluarga rendah berisiko 6 kali menjadi stunting dibandingkan anak dengan pendapatan keluarga tinggi. Pendapatan berkaitan dengan daya beli masyarakat terhadap pangan. Pangan yang baik dan bergizi dibutuhkan oleh balita dalam masa pertumbuhanya. Adapun di wilayah Kab. Kuningan harga pangan sudah cukup tinggi, akan tetapi upah minimum rakyat (UMR) nya masih rendah dibandingkan kabupaten tetangganya. Maka bagi sebagian masyarakat yang bekerja di wilayah Kab. Kuningan mereka masih mendapatkan pendapatan yang pas-pasan atau kurang untuk keluarganya, apalagi ditambah dengan anggota rumah tangga yang banyak.

\section{Kesimpulan}

Tinggi badan ayah, pendidikan terakhir ibu dan pendapatan keluarga merupakan faktor yang berhubungan signifikan dengan kejadian stunting. Adapun tinggi badan ibu tidak berhubungan dengan kejadian stunting. Latar belakang pendidikan ibu merupakan siginifikan prediktor terhadap kejadian stunting pada anak balita usia 2459 bulan. Anak balita yang memiliki ibu dengan latar belakang pendidikan $\leq$ SMP 2,74 lebih berisiko mengalammi kejadian stunting. Dengan demikian saran dari penelitian ini adalah perlu adanya peningkatan upaya promosi kesehatan tentang gizi anak serta kesehatan kehamilan pada ibu balita. Pembentukan komunitas literasi kesehatan pada masyarakat perempuan perlu ditingkatkan.

\section{Daftar Pustaka}

Abuya, B. A., Ciera, J., \& Kimani-Murage, E. (2012). Effect of mother's education on child's nutritional status in the slums of Nairobi. BMC pediatrics, 12(1), 80.

Bove, I., Miranda, T., Campoy, C., Uauy, R., \& Napol, M. (2012). Stunting, overweight and child development impairment go hand in hand as key problems of early infancy: Uruguayan case. Early human development, 88(9), 747-751. 
Deshmukh, P. R., Sinha, N., \& Dongre, A. R. (2013). Social determinants of stunting in rural area of Wardha, Central India. medical journal armed forces india, 69(3), 213-217.

Kementerian Kesehatan, R. (2015). Infodatin Pusat Data dan Informasi Kementrian Kesehatan RI Situasi Balita Pendek. Jakarta. Pusat Data dan Informasi Kementerian Kesehatan RI.

Kementerian Kesehatan, R. (2016). Infodatin Pusat Data dan Informasi Kementrian Kesehatan RI Situasi Balita Pendek. Jakarta. Pusat Data dan Informasi Kementerian Kesehatan RI.

Kementrian Kesehatan, R. (2018). Buku Saku Pemantauan Status Gizi Tahun 2017. In.

Laksminingsih, E. (2018). Can early initiation to breastfeeding prevent stunting in 6-59 months old children? Journal of Health Research, 32(5), 334-341.

Lee, J., Houser, R. F., Must, A., de Fulladolsa, P. P., \& Bermudez, O. I. (2010). Disentangling nutritional factors and household characteristics related to child stunting and maternal overweight in Guatemala. Economics \& Human Biology, 8(2), 188-196.
Lestari, W., Margawati, A., \& Rahfiludin, Z. (2014). Faktor risiko stunting pada anak umur 6-24 bulan di kecamatan Penanggalan Kota Subulussalam Provinsi Aceh. Jurnal Gizi Indonesia (The Indonesian Journal of Nutrition), 3(1), 37-45.

Rachmi, C. N., Agho, K. E., Li, M., \& Baur, L. A. (2016). Stunting coexisting with overweight in $2 \cdot 0$ 4. 9-year-old Indonesian children: prevalence, trends and associated risk factors from repeated crosssectional surveys. Public health nutrition, 19(15), 2698-2707.

Rachmi, C. N., Agho, K. E., Li, M., \& Baur, L. A. (2016). Stunting, underweight and overweight in children aged 2.0-4.9 years in Indonesia: prevalence trends and associated risk factors. PLOS ONE, 11(5), e0154756.

Semba, R. D., Kalm, L. M., De Pee, S., Ricks, M. O., Sari, M., \& Bloem, M. W. (2007). Paternal smoking is associated with increased risk of child malnutrition among poor urban families in Indonesia. Public health nutrition, 10(1), 7-15.

TNP2K. (2017). 100 Kabupaten/Kota Prioritas Untuk Intervensi Anak Kerdil (Stunting). In. 